\title{
Viral Vaccine
}

National Cancer Institute

\section{Source}

National Cancer Institute. Viral Vaccine. NCI Thesaurus. Code C96404.

Any vaccine preparation composed of a live, attenuated, inactivated, killed or recombinant virus. Administration of a viral vaccine is to provide prophylaxis against viral disease or used as a vehicle to treat cancers. 